\title{
Projekcija količine i energetskog potencijala miješanog komunalnog otpada u Republici Hrvatskoj
}

\author{
T. Domanovac, ${ }^{a^{*}}$ I. Sutlović, ${ }^{b}$ V. Filipan, ${ }^{b}$ D. Kučić Grgić, ${ }^{b}$ \\ M. Šabić Runjavec ${ }^{b}$ i M. Vuković Domanovac ${ }^{b}$ \\ a IPZ UNIPROJEKT TERRA, Voćarska cesta 68, 10000 Zagreb \\ • Sveučilište u Zagrebu, Fakultet kemijskog inženjerstva i tehnologije, Marulićev trg 19, 10000 Zagreb
}

Ovo djelo je dano na korištenje pod Creative Commons Attribution 4.0 International License

\begin{abstract}
Sažetak obradom biorazgradive frakcije otpada. opće potrošnje energije za 2018. godinu.

Ključne riječi

Komunalni otpad, količine otpada, sastav otpada, energetski potencijal otpada, bioplin
\end{abstract}

U ovom je radu procijenjen energetski potencijal miješanog komunalnog otpada koji preostaje nakon ispunjavanja propisanih i planiranih ciljeva gospodarenja komunalnim otpadom, nakon obrade u postrojenjima za mehaničko-biološku obradu. Tom obradom proizvodi se kruto gorivo iz otpada ili električna i toplinska energija u slučaju proizvodnje bioplina anaerobnom

Radi analize, 2026. je pretpostavljena kao godina izgradnje centara za gospodarenje otpadom. Ukupni energetski potencijal koji je moguće iskoristiti oporabom otpada iznosi oko 5,3 PJ, odnosno iznosi oko 3,71 \% od količine energije iz sektora ukupne

\section{Uvod}

Gospodarenje otpadom igra veoma važnu ulogu u zaštiti okoliša i održivom razvoju. ${ }^{1,2}$ Sektor gospodarenja otpadom, naročito komunalnim otpadom, donedavno je bio na vrlo niskom stupnju razvoja. Procesom pristupanja i ulaska Republike Hrvatske u Europsku uniju otvorile su se mogućnosti sufinanciranja sustava gospodarenja komunalnim otpadom, što je uvelike doprinijelo početku izgradnje kapitalnih objekata za njegovu obradu, poput centara za gospodarenje otpadom (CGO) s postrojenjima za mehaničko-biološku obradu (MBO). Osobito važan problem u gospodarenju komunalnim otpadom je izrada cjelovitog sustava koji će biti usklađen s propisima, odnosno ciljevima gospodarenja otpadom, posebice kvantitativnim ciljevima gospodarenja određenim tokovima komunalnog otpada poput reciklabilnog otpada i biootpada. ${ }^{3-6}$

Miješani komunalni otpad (MKO) predstavlja ostatak koji preostaje nakon odvojeno sakupljenih vrsta komunalnog otpada, a njegov udio danas iznosi oko $75 \%$ \%. $^{7-9}$ Kao i u svakom toku otpada, tako i u ovom postoji određeni potencijal za oporabu, odnosno iskorištavanje materijalnog

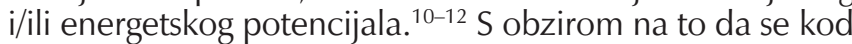
miješanog komunalnog otpada radi o heterogenoj smjesi različitih vrsta otpada različitih svojstava, prilikom njegove obrade računa se, uglavnom, na energetski potencijal u obliku proizvodnje goriva iz otpada $(\mathrm{GlO})^{13-15}$ ili proizvodnje bioplina nastalog anaerobnom obradom biorazgradive organske frakcije miješanog komunalnog otpada. ${ }^{16-20}$

U ovom radu prikazana je procjena količina i hipotetskog energetskog potencijala komunalnog otpada koji se planira

*Autor za dopisivanje: Tomislav Domanovac, dipl. ing. kem. tehn., univ. spec. oecoing. E-pošta: tomislav@ipz-uniprojekt.hr obrađivati u Republici Hrvatskoj u 2026. godini, kao pretpostavljenoj godini dovršetka izgradnje i početka rada svih CGO-ova, u slučaju da navedeni CGO-i izgrade bioplinska postrojenja za biorazgradivu frakciju MKO-a. Takva procjena, koja se oslanja na terenska istraživanja sastava realnih uzoraka MKO-a, analizu i obradu podataka te modeliranje, temelj je za daljnje financijske i ekonomske studije te analize troškova i koristi iskorištavanja energetskog potencijala iz komunalnog otpada.

\section{Materijali i metode}

\subsection{Postojeće količine otpada i ciljevi gospodarenja otpadom}

Količine miješanog komunalnog otpada koje preostaju za obradu nakon izdvojeno sakupljenih vrsta otpada čije su količine usklađene s kvantitativnim ciljevima gospodarenja otpadom, temelje se na postojećim službenim podatcima o količinama otpada prijavljenim u Registru onečišćavanja okoliša (ROO), ${ }^{7}$ godišnjem izvješću o komunalnom otpa$\mathrm{du}^{8}$ i publikaciji ${ }^{9}$ resornog ministarstva s preporučenim sastavom miješanog komunalnog otpada te metodologiji određivanja sastava ukupnog toka komunalnog otpada. Ti podatci o ukupnim količinama i sastavu komunalnog otpada potrebni su radi utvrđivanja budućih količina prema tokovima komunalnog otpada da bi se postigli ciljevi gospodarenja otpadom koji su usuglašeni s nacionalnim planom gospodarenja otpadom (PGO RH) ${ }^{3}$ i Zakonom o održivom gospodarenju otpadom (ZOGO) ${ }^{4}$ kao osnovnim propisom koji regulira gospodarenje otpadom u Republici Hrvatskoj. Sažeti pregled ciljeva gospodarenja otpadom prikazan je u tablici 1. 
Tablica 1 - Pregled ciljeva gospodarenja otpadom

Table 1 - Review of waste management objectives

\begin{tabular}{|c|c|c|}
\hline \multirow{2}{*}{$\begin{array}{l}\text { Dokument } \\
\text { Document }\end{array}$} & \multirow{2}{*}{$\begin{array}{l}\text { Cilj } \\
\text { Target }\end{array}$} & $\begin{array}{l}\text { Rok za postizanje cilja } \\
\text { Deadline to achieve the target }\end{array}$ \\
\hline & & $\begin{array}{l}\text { Godina } \\
\text { Year }\end{array}$ \\
\hline \multirow{3}{*}{ ZOGO } & $\begin{array}{l}\text { Količina papira, plastike, stakla i metala iz kućanstava pripremljenih za } \\
\text { recikliranje od ukupne količine tih materijala } 50 \%\end{array}$ & \multirow{3}{*}{2020.} \\
\hline & $\begin{array}{c}\text { Količina odloženoga biorazgradivog komunalnog otpada } \\
\text { od količine proizvedene 1997.: } 35 \%\end{array}$ & \\
\hline & Količina neopasnog građevnog otpada za oporabu: 70 \% & \\
\hline \multirow{18}{*}{ PGO RH } & $\begin{array}{l}\text { 1. Unaprijediti sustav gospodarenja komunalnim otpadom (KO) u odnosu na } \\
\text { 2015. god }\end{array}$ & \multirow{18}{*}{2022.} \\
\hline & Cilj 1.1: Smanjiti ukupnu količinu proizvedenog KO-a za 5 \% & \\
\hline & $\begin{array}{l}\text { Cilj 1.2: Odvojeno prikupiti } 60 \% \text { komunalnog otpada } \\
\text { (ponajprije papir, staklo, plastika, metal i dr.) }\end{array}$ & \\
\hline & Cilj 1.3: Odvojeno prikupiti 40 \% biootpada iz KO-a & \\
\hline & Cilj 1.4: Odložiti manje od 25 \% komunalnog otpada & \\
\hline & 2. Unaprijediti sustav gospodarenja posebnim kategorijama otpada (PKO) & \\
\hline & Cilj 2.1: Odvojeno prikupiti 75 \% građevnog otpada u odnosu na 2015. god & \\
\hline & $\begin{array}{c}\text { Cilj 2.2: Unaprijediti sustav gospodarenja otpadnim muljem iz uređaja za } \\
\text { pročišćavanje otpadnih voda }\end{array}$ & \\
\hline & Cilj 2.3: Unaprijediti sustav gospodarenja ambalažnim otpadom & \\
\hline & Cilj 2.4: Uspostaviti sustav gospodarenja morskim otpadom & \\
\hline & $\begin{array}{l}\text { Cilj 2.5: Uspostaviti sustav gospodarenja podrtina i } \\
\text { potonulih stvari na morskom dnu }\end{array}$ & \\
\hline & Cilj 2.6: Unaprijediti sustav gospodarenja ostalim posebnim kategorijama otpada & \\
\hline & 3. Unaprijediti sustav gospodarenja opasnim otpadom & \\
\hline & 4. Sanirati lokacije onečišćene otpadom & \\
\hline & 5. Kontinuirano provoditi izobrazno-informativne aktivnosti & \\
\hline & 6. Unaprijediti informacijski sustav gospodarenja otpadom & \\
\hline & 7. Unaprijediti nadzor nad gospodarenjem otpadom & \\
\hline & 8. Unaprijediti upravne postupke u gospodarenju otpadom & \\
\hline
\end{tabular}

\subsection{Projekcija budućih količina i tokova otpada}

Radi davanja dugoročnih procjena nakon 2022. godine, u obzir su uzete pretpostavke Europske komisije vezane uz demografska kretanja ${ }^{21}$ i ciljevi gospodarenja komunalnim otpadom prema Direktivi EU 2018/851 za 2035. godinu, gdje se navodi da do 2035. pripremu za ponovnu uporabu i recikliranje komunalnog otpada treba povećati na najmanje $65 \%$ mase. $^{6}$

Stoga, da bi se mogle dati kvantitativne procjene tokova otpada koje su usuglašene s propisanim ciljevima gospodarenja otpadom, za razdoblje do 2022. godine u obzir su uzete sljedeće pretpostavke:

- obuhvatnost stanovništva RH organiziranim odvozom otpada: $100 \%$,

- specifična količina komunalnog otpada po stanovniku prati promjenu BDP-a (prosječna godišnja stopa oko 1,2\%), ali se od 2015. do 2022. godine smanjuje po prosječnoj godišnjoj stopi od oko $1,9 \%$ radi ispunjavanja cilja 1.1,

- radi istodobnog postizanja cilja iz ZOGO-a i ciljeva $1.2 \mathrm{i}$ 1.4 iz PGO RH, da će količine odvojeno sakupljenog papira/kartona, plastike, stakla i metala od ukupnih količina navedenih materijala u 2020. godini rasti do $64,8 \%$, $\mathrm{s}$ uračunatim prosječnim udjelom nečistoća u izdvojeno sakupljenim vrstama otpada od $10 \%$,

- da će ukupne količine odvojenog komunalnog otpada radi reciklaže od ukupnih količina komunalnog otpada rasti do $60,0 \%$ u 2022. godini radi ispunjavanja ciljeva 1.2 i 1.4 ,

- da će udio odvojeno sakupljenog biootpada za biološku obradu u 2022. godini rasti do $40 \%$ radi istodobnog ispunjavanja ciljeva 1.2, 1.3 i 1.4.

U predmetnom planskom razdoblju neće doći do značajnih promjena u sastavu komunalnog otpada iz kućanstava 
i njemu sličnog otpada, a realizacija CGO-a bit će u skladu s dokumentom Vlade RH o implementaciji PGO RH. ${ }^{5}$

Za potrebe dugoročne projekcije tokova otpada do 2050. godine pretpostavljeni su sljedeći ciljevi:

- smanjenje specifične količine komunalnog otpada po glavi stanovnika u 2028. godini za $2 \%$ u odnosu na specifičnu količinu u 2022. godini te 1,5\%-tno smanjenje specifične količine u 2035. godini u odnosu na 2028. godinu,

- udio izdvojeno sakupljenog komunalnog otpada u 2028. godini od $67 \%$ radi ispunjavanja uvjeta iz Direktive EU 2018/851 za 2025. godinu,

- udio izdvojeno sakupljenog komunalnog otpada u 2035. godini od $75 \%$ radi ispunjavanja uvjeta iz Direktive EU 2018/851 za 2030. i 2035. godinu,

- udio izdvojeno sakupljenih suhih reciklata (papir/karton, plastika, staklo i metal) u 2028. godini u iznosu od $70,3 \%$ od ukupne količine tih komponenti u 2028. godini, s maksimalno $10 \%$ nečistoća,

- udio izdvojeno sakupljenog biootpada u 2028. godini u iznosu od 60 \% od ukupne količine biootpada u 2028. godini.

U predmetnom planskom razdoblju neće doći do značajnih promjena u sastavu komunalnog otpada iz kućanstava i njemu sličnog otpada. Procijenjeni broj stanovnika RH u 2030. godini iznosio bi 3.900 .000 stanovnika uz $100 \%$-tnu obuhvatnost stanovništva organiziranim odvozom otpada.
Na temelju navedenih pretpostavki, u tablici 2 prikazana je u kontrolnim godinama projekcija osnovnih tokova komunalnog otpada koji je potrebno izdvojeno sakupiti radi reciklaže (lijevi dio tablice) ili obraditi prije oporabe ili zbrinjavanja (desni dio tablice).

Kao pretpostavljena godina realizacije sve potrebne infrastrukture za obradu odvojeno sakupljenog otpada za reciklažu, kao i obradu miješanog komunalnog otpada i ostatka iz materijalne oporabe odvojeno sakupljenog reciklabilnog otpada, za potrebe ove analize uzeta je 2026. godina.

\subsection{Oporaba i zbrinjavanje komunalnog otpada}

Na temelju sastava, količina i tokova komunalnog otpada te ciljeva gospodarenja otpadom, na slici 1 prikazana je shema koja povezuje tokove s mjestima oporabe ili zbrinjavanja komunalnog otpada na primjeru 2026. godine.

Odvojeno sakupljene suhe reciklate $\mathrm{i}$ ostale reciklabilne vrste otpada prije recikliranja potrebno je pročistiti radi postizanja tražene čistoće materijala, što se postiže ručnim ili automatskim sortiranjem uz ručnu kontrolu kvalitete, na lokalnim ili centraliziranim objektima za obradu, na tzv. sortirnicama otpada. Pročišćeni i za recikliranje pripremljeni materijali dalje se upotrebljavaju kao sekundarne sirovine. Sličan tijek je i za odvojeno sakupljeni biootpad i dobivanje digestata ili komposta kao proizvoda biološke obrade u anaerobnim ili aerobnim uvjetima.

Tablica 2 - Projekcija osnovnih tokova komunalnog otpada

Table 2 - Projection of basic flows of municipal waste

\begin{tabular}{|c|c|c|c|c|c|c|c|}
\hline $\begin{array}{l}\text { Godina } \\
\text { Year }\end{array}$ & $\begin{array}{c}\text { Izdvojeno } \\
\text { sakupljeni suhi } \\
\text { reciklati } \\
\text { Separately } \\
\text { collected dry } \\
\text { recyclables }\end{array}$ & $\begin{array}{c}\text { Izdvojeno } \\
\text { sakupljeni ostali } \\
\text { otpad } \\
\text { Separately } \\
\text { collected other } \\
\text { waste }\end{array}$ & $\begin{array}{l}\text { Izdvojeno } \\
\text { sakupljeni } \\
\text { biootpad } \\
\text { Separately } \\
\text { collected } \\
\text { biowaste }\end{array}$ & $\begin{array}{l}\text { Miješani } \\
\text { komunalni } \\
\text { otpad } \\
\text { Mixed } \\
\text { municipal } \\
\text { waste }\end{array}$ & $\begin{array}{c}\text { Ostatak iz } \\
\text { materijalne } \\
\text { oporabe } \\
\text { Material } \\
\text { recovery residue }\end{array}$ & $\begin{array}{c}\text { Ostali } \\
\text { komunalni } \\
\text { otpad } \\
\text { (glomazni i dr.) } \\
\text { Other municipal } \\
\text { waste } \\
\text { (bulky, etc.) }\end{array}$ & $\begin{array}{l}\text { Ukupno } \\
\text { komunalni otpad } \\
\text { za oporabu ili } \\
\text { zbrinjavanje } \\
\text { Total municipal } \\
\text { waste for recovery } \\
\text { or disposal }\end{array}$ \\
\hline & $\begin{array}{l}\text { tgod }^{-1} \\
\text { tyear }^{-1}\end{array}$ & $\begin{array}{l}\text { tgod }^{-1} \\
\text { tyear }^{-1}\end{array}$ & $\begin{array}{l}\text { tgod }^{-1} \\
\text { tyear }^{-1}\end{array}$ & $\begin{array}{l}\text { tgod }^{-1} \\
\text { tyear }^{-1}\end{array}$ & $\begin{array}{l}\text { tgod }^{-1} \\
\text { tyear }^{-1}\end{array}$ & $\begin{array}{l}\text { tgod }^{-1} \\
\text { tyear }^{-1}\end{array}$ & $\begin{array}{l}\text { tgod }^{-1} \\
\text { tyear }^{-1}\end{array}$ \\
\hline 2020. & 555.816 & 153.990 & 159.952 & 761.947 & 116.077 & 87.132 & - \\
\hline 2021. & 578.641 & 166.079 & 191.942 & 673.962 & 125.270 & 87.402 & - \\
\hline 2022. & 610.134 & 180.163 & 213.269 & 585.414 & 136.501 & 87.626 & - \\
\hline 2025. & 571.691 & 168.812 & 241.988 & 567.095 & 127.900 & 82.105 & - \\
\hline 2026. & 567.937 & 167.703 & 256.749 & 544.284 & 127.060 & 81.566 & 752.911 \\
\hline 2028. & 558.531 & 164.926 & 289.026 & 498.686 & 124.956 & 80.215 & 703.857 \\
\hline 2030. & 583.280 & 162.581 & 284.917 & 458.906 & 126.449 & 79.074 & 664.429 \\
\hline 2035. & 654.023 & 158.760 & 278.220 & 363.668 & 131.922 & 77.216 & 572.806 \\
\hline 2040. & 655.386 & 159.090 & 278.800 & 364.425 & 132.197 & 77.377 & 573.999 \\
\hline 2045. & 637.588 & 154.770 & 271.229 & 354.529 & 128.607 & 75.276 & 558.412 \\
\hline 2050. & 613.252 & 148.863 & 260.876 & 340.997 & 123.698 & 72.402 & 537.098 \\
\hline
\end{tabular}




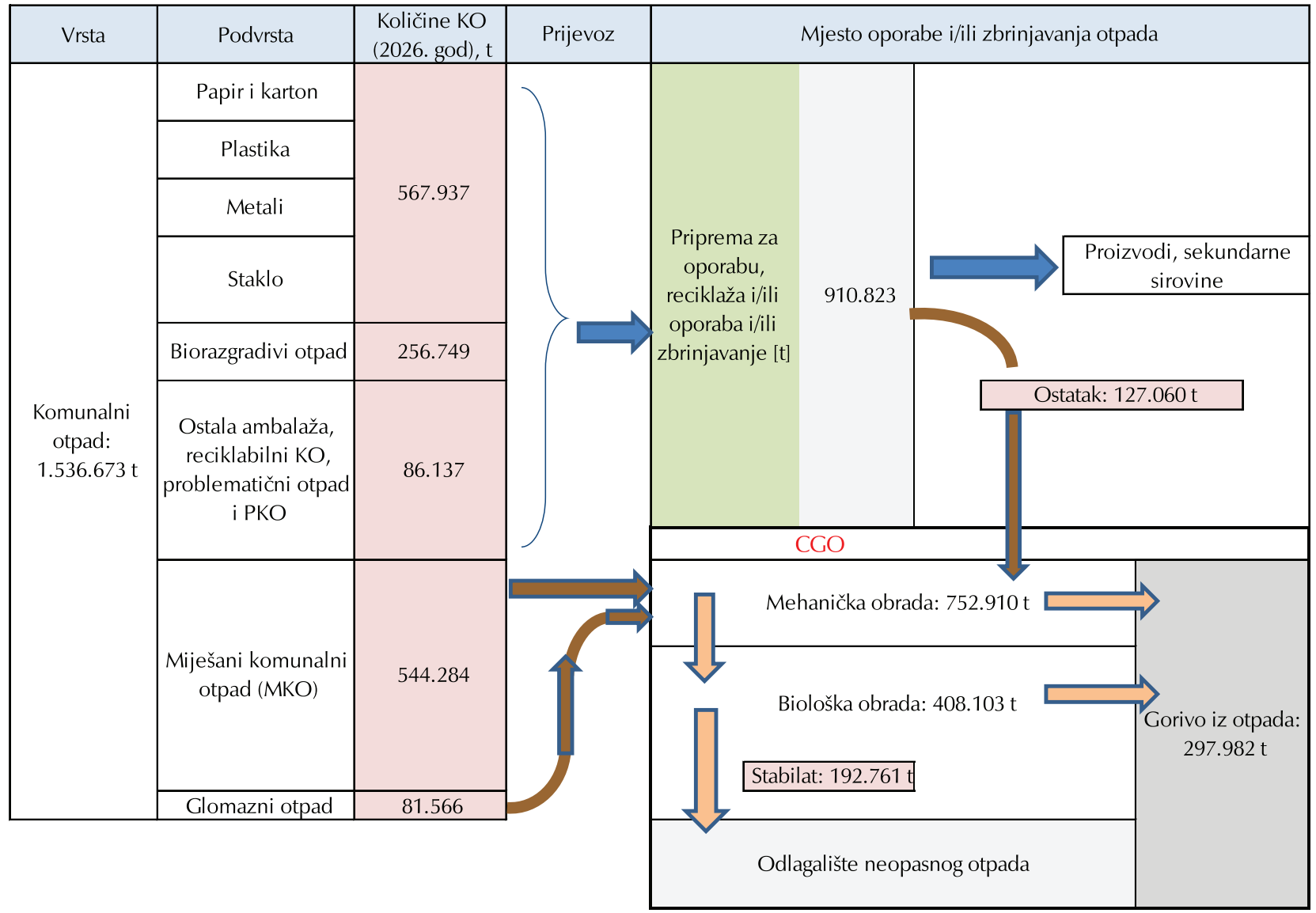

Slika 1 - Tokovi komunalnog otpada u 2026. godini

Fig. 1 - Municipal waste flows in 2026

Miješani komunalni otpad i ostatak iz sortirnica obrađuje se na županijskim ili regionalnim centrima za gospodarenje otpadom. Kao proizvod obrade nastaje stabilizirana biorazgradiva frakcija komunalnog otpada koja se zbrinjava odlaganjem na odlagalištima neopasnog otpada u sklopu tih centara te gorivo iz otpada koje može biti standardizirano čvrsto gorivo (engl. solid recovered fuel, SRF), ${ }^{22}$ opisano u tablici 3, ili gorivo u plinovitom stanju, tzv. bioplin dobiven obradom biorazgradive frakcije komunalnog otpada $u$ anaerobnim uvjetima.

\subsection{Fizikalno-kemijska svojstva komunalnog otpada}

Za procjenu ogrjevne vrijednosti dobivenog $\mathrm{GIO}$-a koristili su se podatci o masenom udjelu te elementarnom sastavu i fizikalno-kemijskim svojstvima komponenata otpada iz raznih literaturnih izvora ${ }^{10-12}$ koji su prikazani u tablici 4.

Za izračun gornje toplinske vrijednosti $\left(\mathrm{H}_{\mathrm{g}}\right)$ primijenjena je modificirana Dulongova empirijska formula (1): ${ }^{11}$

$$
\mathrm{H}_{\mathrm{g}}\left(\mathrm{kJ} \mathrm{kg}{ }^{-1} \text { s.t. }\right)=337 \mathrm{C}+1419(\mathrm{H}-1 / 8 \mathrm{O})+93 \mathrm{~S}+23 \mathrm{~N}(1)
$$

Tablica 3 - Gorivo iz otpada (GIO/SRF prema HRN EN 15359:2012)

Table 3 - Refuse derived fuel (SRF according to HRN EN 15359: 2012)

\begin{tabular}{|c|c|c|c|c|c|c|c|}
\hline \multirow{2}{*}{$\begin{array}{l}\text { Klasifikacijsko svojstvo } \\
\text { Classification property }\end{array}$} & \multirow{2}{*}{$\begin{array}{c}\text { Statistička mjera } \\
\text { Statistical } \\
\text { measure }\end{array}$} & \multirow{2}{*}{$\begin{array}{l}\text { Jedinica } \\
\text { Unit }\end{array}$} & \multicolumn{5}{|c|}{$\begin{array}{l}\text { Klase } \\
\text { Class }\end{array}$} \\
\hline & & & 1 & 2 & 3 & 4 & 5 \\
\hline $\begin{array}{l}\text { Neto ogrjevna } \\
\text { vrijednost }\left(\mathrm{H}_{\mathrm{d}}\right)\end{array}$ & $\begin{array}{c}\text { Srednja } \\
\text { vrijednost }\end{array}$ & MJ kg-1 v.t. & $=>25$ & $=>20$ & $=>15$ & $=>10$ & $=>3$ \\
\hline Klor $(\mathrm{Cl})$ & $\begin{array}{c}\text { Srednja } \\
\text { vrijednost }\end{array}$ & \% s.t. & $<=0,2$ & $<=0,6$ & $<=1,0$ & $<=1,5$ & $<=3$ \\
\hline \multirow{2}{*}{ Živa (Hg) } & Median & $\mathrm{mgMJ}^{-1}$ v.t. & $<=0,02$ & $<=0,03$ & $<=0,08$ & $<=0,15$ & $<=0,50$ \\
\hline & 80. percentil & $m g \mathrm{MJ}^{-1}$ v.t. & $<=0,04$ & $<=0,06$ & $<=0,16$ & $<=0,30$ & $<=1,00$ \\
\hline
\end{tabular}


Tablica 4 - Fizikalno-kemijska svojstva komponenti otpada

Table 4 - Physicochemical properties of waste components

\begin{tabular}{|c|c|c|c|c|c|c|c|c|c|c|}
\hline \multirow[t]{2}{*}{$\begin{array}{l}\text { Sastavnica otpada } \\
\text { Waste component }\end{array}$} & \multicolumn{10}{|c|}{$\begin{array}{l}\text { Udio } / \% \\
\text { Share } / \%\end{array}$} \\
\hline & C & $\mathrm{H}$ & $\mathrm{O}$ & $\mathrm{N}$ & S & $\begin{array}{l}\text { Pepeo } \\
\text { Ash }\end{array}$ & $\begin{array}{l}\text { Vlaga } \\
\text { Moisture }\end{array}$ & $\begin{array}{l}\text { Hlapljivo } \\
\text { Volatile }\end{array}$ & $\begin{array}{l}\text { Fiksni C } \\
\text { Fixed C }\end{array}$ & $\begin{array}{c}\text { Negorivo } \\
\text { Non-combustible }\end{array}$ \\
\hline guma & 82,0 & 10,1 & 0,5 & 0,0 & 1,9 & 36,4 & 1,9 & 83,9 & 4,9 & 9,9 \\
\hline papir & 45,2 & 5,9 & 44,3 & 0,4 & 0,2 & 7,6 & 10,5 & 82,6 & 10,0 & 1,4 \\
\hline karton & 45,8 & 6,2 & 44,9 & 0,2 & 0,2 & 6,1 & 10,9 & 80,4 & 9,6 & 5,0 \\
\hline staklo & 0,5 & 0,1 & 0,4 & 0,1 & 0,0 & 0,0 & 2,0 & 0,0 & 0,0 & 98,0 \\
\hline plastika, tvrda & 78,7 & 11,3 & 5,3 & 0,6 & 0,3 & 2,2 & 8,7 & 97,0 & 1,0 & 2,0 \\
\hline metal & 4,5 & 0,6 & 4,3 & 0,1 & 0,0 & 0,0 & 5,0 & 0,0 & 0,0 & 95,0 \\
\hline drvo & 47,2 & 6,2 & 44,4 & 0,5 & 0,2 & 1,3 & 13,8 & 83,1 & 10,9 & 0,6 \\
\hline kuhinjski otpad & 45,5 & 6,6 & 32,3 & 2,8 & 0,3 & 7,3 & 70,2 & 57,6 & 9,0 & 5,0 \\
\hline tekstil & 47,6 & 6,2 & 31,3 & 2,8 & 0,3 & 5,2 & 12,8 & 88,6 & 6,2 & 6,5 \\
\hline biootpad & 45,0 & 5,6 & 37,7 & 1,5 & 0,2 & 9,6 & 53,9 & 73,0 & 17,4 & 0,5 \\
\hline inertni otpad & 26,3 & 3,0 & 2,0 & 0,5 & 0,2 & 68,0 & 8,0 & 0,0 & 0,0 & 0,0 \\
\hline tetrapak & 59,2 & 9,3 & 30,1 & 0,1 & 0,1 & 1,2 & 3,5 & 90,9 & 4,5 & 0,0 \\
\hline koža i kosti & 60,0 & 8,0 & 11,6 & 10,0 & 0,4 & 10,0 & 10,0 & 68,5 & 12,5 & 9,0 \\
\hline plastika, meka & 77,4 & 12,9 & 1,8 & 0,1 & 0,1 & 8,8 & 19,1 & 90,1 & 1,1 & 2,0 \\
\hline
\end{tabular}

gdje je: $\mathrm{C}$ - maseni \% ugljika, $\mathrm{H}$ - maseni \% vodika, $\mathrm{O}-$ maseni \% kisika, $\mathrm{S}$ - maseni \% sumpora i $\mathrm{N}$ - maseni \% dušika, a u proračun se upisuju kao bezdimenzijske veličine.

\section{Rezultati i rasprava}

\subsection{Opis tehnološkog procesa obrade komunalnog otpada}

lako dio suhih reciklata, u prvom redu plastika te papir i karton, mogu biti iskorišteni u proizvodnji goriva iz otpa$\mathrm{da}$, radi ispunjavanja ciljeva gospodarenja otpadom taj tok otpada, kao i drugi reciklabilni otpadni materijali i posebne kategorije otpada, nisu uzeti u obzir prilikom procjene energetskog potencijala iz otpada. Slično se pretpostavlja i za odvojeno sakupljeni biootpad, premda se i njegovom biološkom obradom u anaerobnim uvjetima može dobiti električna i toplinska energija, a krajnji rezultat je digestat/ kompost kao produkt materijalne oporabe. ${ }^{11,12}$

Kao rezultat izrade masene bilance tokova otpada usklađenih s važećim propisima i ciljevima gospodarenja otpadom, iz tablice 2 je vidljivo da je za obradu na centrima za gospodarenje otpadom, dakle za obradu miješanog komunalnog otpada i ostatka iz materijalne oporabe, potrebno predvidjeti postrojenja ukupnog kapaciteta oko $753.000 \operatorname{tgod}^{-1}$, gdje je najveće opterećenje sustava u početnim godinama s trendom opadanja iskorištenja u prosjeku za oko 29 \% nakon 25 godina rada.

Nakon ulaska miješanog i ostatnog komunalnog otpada u CGO, on se mehaničkim separacijskim procesima razdvaja na: a) krupnu, suhu i pretežno gorivu frakcija (oko $45 \%$ ) te b) na sitnu, vlažnu i pretežno biorazgradivu frakciju komunalnog otpada (oko 55 \%).

Iz krupne, gorive frakcije rafinacijom se dobiva gorivo iz otpada i ostatak (metali, PVC i inertni otpad). Ovisno o trenutačnim potrebama tržišta, moguće je proizvoditi GIO ciljane količine i klase upotrebljavajući optičke separatore za izdvajanje plastike i papira. Obično se proizvodi GIO/ SRF klase 1 te GIO/SRF klase 3 ili 4.

Biorazgradiva frakcija otpada stabilizira se biološkom obradom $u$ aerobnim i/ili anaerobnim uvjetima, pri čemu nastaju plinovi razgradnje. Plinovi aerobne biorazgradnje se prije emisije u zrak obrađuju na biofiltarskom postrojenju. ${ }^{11,12}$ Ostatak obrade $u$ aerobnim uvjetima (stabilat) $\mathrm{s}$ malim udjelom nerazgrađenog ugljika odlaže se na odlagalištu neopasnog otpada. Produkt biološke obrade u anaerobnim uvjetima je bioplin koji se kao gorivo u plinskom motoru upotrebljava za dobivanje električne i toplinske energije. Dobivena energija dijelom se iskorištava u procesu biološke obrade (oko $25 \%$ ), ${ }^{23,24}$ a višak proizvedene energije moguće je iskoristiti u drugim postrojenjima u sklopu CGO-a ili predati u elektro-energetsku mrežu. Digestat dobiven anaerobnom obradom biorazgradive frakcije MKO-a potrebno je prije odlaganja na odlagalištu neopasnog otpada dodatno stabilizirati aerobnom biorazgradnjom. U slučaju anaerobne obrade izdvojeno sakupljenog biootpada, digestat se može, ovisno o analizama i sukladno propisima, izravno upotrebljavati kao gnojivo u poljoprivredi. 
Za potrebe analize pretpostavit će se biološka obrada biorazgradive frakcije komunalnog otpada postupkom suhe fermentacije koja se može voditi u termofilnim ili mezofilnim uvjetima, uz dobivanje bioplina radi proizvodnje električne i toplinske energije.

\subsection{Proizvodnja GIO-a}

Pretpostavljeni prosječni sastav $\mathrm{GlO}$-a više i niže kvalitete (SRF klasa 1 i SRF klasa 4) prikazan je na slici 2.
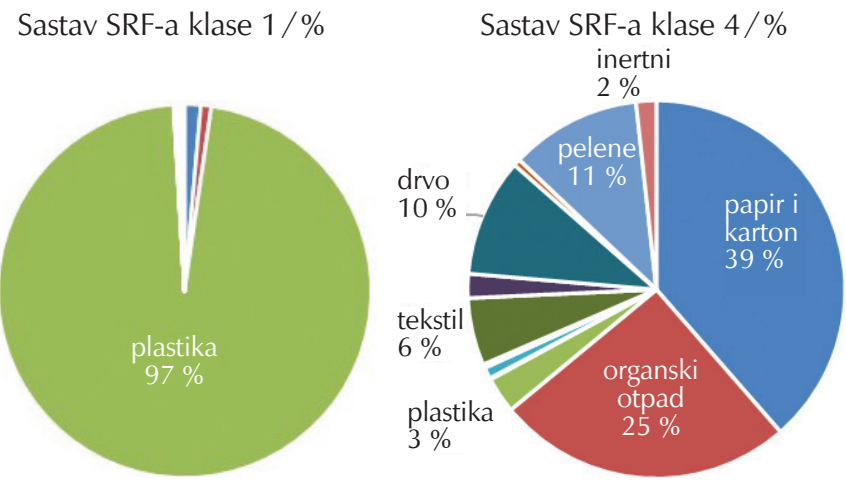

Slika 2 - Pretpostavljeni prosječni udjeli komponenti u GIO-u više kvalitete (lijevo) i GlO-u niže kvalitete (desno)

Fig. 2 - Assumed average component shares in higher quality SRF (left), and lower quality SRF (right)

Na temelju podataka iz tablice 4 i slike 2, procijenjeni su prosječni elementarni sastavi GlO-a više i niže kvalitete, tj. procijenjene su njihove bruto kemijske formule čiji su koeficijenti uvršteni u modificiranu Dulongovu empirijsku formulu (1) ${ }^{11}$ za izračun gornje toplinske vrijednosti $\left(\mathrm{H}_{\mathrm{g}}\right)$.

Procijenjene godišnje količine te karakteristike GIO-a više i niže kvalitete prikazane su u tablici 5. Dobivene vrijednosti su u skladu s objavljenim podatcima. ${ }^{14,15}$ Ako je pristup da se maksimizira količina GIO-a (SRF klase I.), tada je iz ukupne ulazne količine komunalnog otpada u CGO-e na području RH od oko 752.911 t god $^{-1}$ (procijenjeni podatak za 2026. godinu) moguće dobiti oko 64.000 t SRF klase 1 i oko 234.000 t SRF klase 4. Radi određivanja klase GIO-a (SRF-a), osim donje toplinske vrijednosti u dostavnom stanju, potrebno je laboratorijski odrediti i vrijednosti drugih klasifikacijskih svojstava sukladno tablici 3.

Dakle, procijenjeni godišnji potencijal GIO-a dobiven mehaničkom rafinacijom gorive frakcije miješanog komunalnog i ostatnog otpada u sklopu CGO-a iznosi oko 4,25 PJ, odnosno oko 1.181 GWh.

\subsection{Proizvodnja bioplina}

Kao što je prethodno navedeno, za procjenu energetskog potencijala biorazgradive frakcije miješanog komunalnog otpada pretpostavljena je biološka obrada u anaerobnim uvjetima gdje je produkt biorazgradnje bioplin. Količina bioplina procijenjena je na temelju laboratorijskih ispitiva-
Tablica 5 - Procijenjene godišnje količine te karakteristike GIO-a više i niže kvalitete

Table 5 -Estimated annual quantities and characteristics of higher and lower quality SRF

\begin{tabular}{l|c|c}
\hline $\begin{array}{l}\text { Pokazatelj } \\
\text { Indicator }\end{array}$ & $\begin{array}{c}\text { SRF klasa 1 } \\
\text { SRF class 1 }\end{array}$ & $\begin{array}{c}\text { SRF klasa 4 } \\
\text { SRF class 4 }\end{array}$ \\
\hline $\begin{array}{l}\text { količina SRF-a za energetsku } \\
\text { oporabu } / \mathrm{tgod}^{-1}\end{array}$ & 64.360 & 233.622 \\
\hline $\begin{array}{l}\text { gornja toplinska } \\
\text { vrijednost } / \mathrm{kJ} \mathrm{kg}^{-1} \text { s.t. }\end{array}$ & 33.528 & 14.387 \\
\hline $\begin{array}{l}\text { gornja toplinska vrijednost } \\
\text { u dostavnom stanju } / \mathrm{kJ} \mathrm{kg}^{-1}\end{array}$ & 29.294 & 10.910 \\
\hline $\begin{array}{l}\text { donja toplinska } \\
\text { vrijednost } / \mathrm{kJ} \mathrm{kg}^{-1} \text { s.t. }\end{array}$ & 32.809 & 13.794 \\
\hline $\begin{array}{l}\text { donja toplinska vrijednost } \\
\text { u dostavnom stanju/ } / \mathrm{kJg}^{-1}\end{array}$ & 28.575 & 10.317 \\
\hline \begin{tabular}{l} 
udio vlage $/ \%$ \\
\hline
\end{tabular} & 12,6 & 24,2 \\
\hline
\end{tabular}

nja realnih reprezentativnih uzoraka biorazgradive frakcije miješanog komunalnog otpada ${ }^{26}$ te empirijskih formula za procjenu parametara biorazgradivosti. ${ }^{27,28}$ Prilikom procjene proizvodnje bioplina s prosječnim udjelom metana od oko $54 \%$ koristili su se podatci o udjelu suhe tvari u biorazgradivoj frakciji MKO-a od oko $62,4 \%$ te bioplinskog potencijala od oko $0,425 \mathrm{Nm}^{3} \mathrm{~kg}^{-1}$ fermentabilne hlapljive tvari čiji je udio u suhoj tvari oko 67,7 \%, što odgovara podatcima iz sličnih provedenih ispitivanja. ${ }^{18-20}$ Ukupna količina bioplina iz oko $408.104 \mathrm{tgod}^{-1}$ biorazgradive frakcije miješanog i ostatnog otpada procjenjuje se iznosom od oko $41,7 \cdot 10^{6} \mathrm{Nm}^{3}$ bioplina. Ako se pretpostavi učinkovitost postrojenja od oko $76 \%$, kao i električna, odnosno toplinska učinkovitost bioplinskog kogeneracijskog postrojenja od $42,5 \%$, odnosno $44,6 \%$, tada je iz procijenjene ulazne količine biorazgradive frakcije od oko $408.104 \mathrm{tgod}^{-1} \mathrm{mo}^{-}$ guće dobiti oko 91,0 GWh električne energije, odnosno oko 95,6 GWh toplinske energije, odnosno oko 0,67 PJ. Ukupna instalirana snaga bioplinskih postrojenja tako bi se mogla povećati za oko $24 \%$ u odnosu na postojeća bioplinska postrojenja instalirane snage oko $50 \mathrm{MW}_{\mathrm{el}}$, koja energiju pretežito proizvode upotrebom stajnjaka s farmi, silaže i drugih organskih ostataka. ${ }^{29}$

Ako se u računicu pod istim gore navedenim uvjetima uzme i količina od oko 289.026 t god $^{-1}$ odvojeno sakupljenog biootpada koji je moguće materijalno oporabiti kombiniranom biološkom obradom u anaerobnim i aerobnim uvjetima radi proizvodnje komposta kao konačnog proizvoda, iz dijela anaerobne biološke obrade moguće je računati s dodatnom količinom bioplina od oko $26,2 \cdot 10^{6} \mathrm{Nm}^{3}$ bioplina te dodatnim energetskim potencijalom od oko 0,42 PJ.

Dakle, ukupni energetski potencijal (računajući GIO i biorazgradivu frakciju $\mathrm{KO}$ ) koji je moguće iskoristiti oporabom otpada iznosi oko 5,4 PJ. Ako se pretpostavi prosječna opća potrošnja energije, koju čini zbroj potrošnje energije u kućanstvima, šumarstvu, poljoprivredi i graditeljstvu, od oko 144,12 $\mathrm{PJ} \mathrm{god}^{-1}$ (podatak za 2018. godinu), ${ }^{30}$ tada udio energetskog potencijala iz miješanog komunalnog i ostatnog otpada te izdvojeno sakupljenog biootpada iznosi oko $3,71 \%$. 


\section{Zaključak}

Sukladno ciljevima gospodarenja otpadom u RH te projekcijama količina komunalnog otpada, od ukupno stvorene godišnje količine komunalnog otpada u 2026. godini od oko $1,54 \cdot 10^{6} \mathrm{t}$, na centrima za gospodarenje otpadom potrebno obraditi oko $753.000 \mathrm{tgod}^{-1}$. Mehaničko-biološkom obradom otpada, koja za potrebe ove analize uključuje mehaničku obradu i rafinaciju gorive frakcije te kombiniranu biološku biorazgradivu frakciju miješanog komunalnog otpada u anaerobnim i aerobnim uvjetima, moguće je proizvesti čvrsto gorivo iz otpada u količini od oko $298.000 \mathrm{tgod}^{-1}$ te oko $41,7 \cdot 10^{6} \mathrm{Nm}^{3}$ bioplina. Ako se pretpostavi ista biološka obrada otpada i za odvojeno sakupljeni biootpad, tada se može računati s dodatnom godišnjom proizvodnjom od oko $26,2 \cdot 10^{6} \mathrm{Nm}^{3}$ bioplina.

Ukupni energetski potencijal koji je moguće iskoristiti oporabom otpada iznosi oko 5,3 PJ, odnosno oko 3,71 \% od količine energije iz sektora ukupne opće potrošnje energije za 2018. godinu. Dobiveni energetsko-tehnički potencijal komunalnog otpada podloga je daljnje studije i analize vezane za razvoj cjelovitog sustava gospodarenja otpadom.

\section{Popis kratica i simbola \\ List of abbreviations and symbols}

\begin{tabular}{|c|c|}
\hline BDP & - bruto domaći proizvod \\
\hline CGO & - centar za gospodarenje otpadom \\
\hline EU & - Europska unija \\
\hline $\mathrm{GIO}$ & - gorivo iz otpada \\
\hline HRN EN & - hrvatska norma europska norma \\
\hline $\mathrm{KO}$ & - komunalni otpad \\
\hline $\mathrm{MBO}$ & - mehaničko-biološka obrada \\
\hline MKO & - miješani komunalni otpad \\
\hline PGO RH & - Plan gospodarenja otpadom Republike Hrvatske \\
\hline PKO & - posebne kategorije otpada \\
\hline PVC & - polivinil klorid \\
\hline $\mathrm{RH}$ & - Republika Hrvatska \\
\hline $\mathrm{ROO}$ & - Registar onečišćavanja okoliša \\
\hline KOG/SRF & $\begin{array}{l}\text { - kruto oporabljeno gorivo } \\
\text { - solid recovered fuel }\end{array}$ \\
\hline ZOGO & - Zakon o održivom gospodarenju otpadom \\
\hline el. & - električna (energija) \\
\hline $\mathrm{H}_{\mathrm{d}}$ & $\begin{array}{l}\text { - donja toplinska vrijednost (neto ogrjevna vrijednost), } \\
\mathrm{kJ} \mathrm{kg}^{-1}\end{array}$ \\
\hline $\mathrm{H}_{\mathrm{g}}$ & - gornja toplinska vrijednost, $\mathrm{kJ} \mathrm{kg}^{-1}$ \\
\hline s.t. & - suha tvar \\
\hline v.t. & $\begin{array}{l}\text { - vlažna tvar } \\
\text { (u dostavnom staniu: "as received", engl.) }\end{array}$ \\
\hline
\end{tabular}

\section{Literatura}

References

1. R. Chandrappa, D. Bhusan Das, Solid Waste Management, Principles and Practice, Springer, Heidelberg, 2012., doi: https://doi.org/10.1007/978-3-642-28681-0.

2. N.-B. Chang, A. Pires, Sustainable Solid Waste Management, A System Engineering Approach, Wiley, New Jersey, 2015. doi: https://doi.org/10.1002/9781119035848.

3. Plan gospodarenja otpadom Republike Hrvatske za razdoblje 2017. - 2022. godine, Narodne novine broj 85/07, 126/10, 31/11 i 46/15.

4. Zakon o održivom gospodarenju otpadom, Narodne novine broj 94/13, 73/17, 14/19 i 98/19.

5. Odluka Vlade RH o Implementaciji Plana gospodarenja otpadom Republike Hrvatske za razdoblje 2017. - 2022. godine od 25. svibnja 2017. godine.

6. Direktiva (EU) 2018/851 Europskog parlamenta i Vijeća od 30. svibnja 2018. o izmjeni Direktive 2008/98/EZ o otpadu, Službeni list Europske unije L 150/109.

7. URL: http://roo.azo.hr/rpt.html?rpt=no\&pbl=roo (22. 12. 2020.), Preglednik registra onečišćavanja okoliša, Ministarstvo gospodarstva i održivog razvoja.

8. Izvješće o komunalnom otpadu za 2018. godinu, Ministarstvo zaštite okoliša i energetike, Zagreb, 2019.

9. Metodologija za određivanje sastava i količina komunalnog odnosno miješanog komunalnog otpada s Naputkom za naručivanje i provedbu određivanja prosječnog sastava komunalnog odnosno miješanog komunalnog otpada, Hrvatska agencija za okoliš i prirodu, Zagreb, 2015.

10. R. H. Perry, D. Green, Perry's Chemical Engineers' Handbook, McGraw-Hill, Inc., New York, 1984.

11. G. Tchobanoglous, H. Theisen, S. Vigil, Integrated Solid Waste Management - Engineering Principles and Management Issues, McGraw-Hill, Inc., 1993.

12. P. T. Williams, Waste Treatment and Disposal, Wiley, 2006., doi: https://doi.org/10.1002/0470012668.

13. G. Pinuccia Martignon, Trends in the use of solid recovered fuels, IEA Bioenergry, 2020.

14. E. C. Rada, M. Ragazzi, RDF/SRF evolution in MSW sector: Coexistence of BMT and selective collection, Int. J. Sustain. Develop. Plann. 10 (1) (2015) 109-119, doi: https://doi. org/10.2495/SDP-V10-N1-109-119.

15. Y.-S. Choi, S. Han, H.-S. Choi, S.-J. Kim, Characterization of Korean solid recovered fuels (SRFs): An analysis and comparison of SRFs, Waste Manage. Res. 30 (4) (2012) 442-449, doi: https://doi.org/10.1177\%2F0734242X12441239

16. C. C. Anyaoku, S. Baroutian, Decentralized anaerobic digestion systems for increased utilization of biogas from municipal solid waste, Renew. Sustain. Energ. Rev. 90 (2018) 982-991, doi: https://doi.org/10.1016/j.rser.2018.03.009.

17. A. N. Matheri, V. L. Sethunya, M. Belaid, E. Muzenda, Analysis of the biogas productivity from dry anaerobic digestion of organic fraction of municipal solid waste, Renew. Sustain. Energ. Rev. 81 (2018) 2328-2334, doi: https://doi. org/10.1016/j.rser.2017.06.041.

18. S. Antognoni, M. Ragazzi, E. C. Rada, Biogas potential of OFMSW through an indirect method, Int. J. Environ. Res. 2 (4) (2013) 83-88 
19. M. Pognani, R. Barrena, X. Font, B. Scaglia, F. Adani, A. Sanchez, Monitoring the organic matter properties in a combined anaerobic/aerobic full-scale municipal source-separated waste treatment plant, Biores. Technol. 101 (2010) 68736877, doi: https://doi.org/10.1016/j.biortech.2010.03.110.

20. M. Chavez-Vazquez, D. M. Bagley, Evaluation of the performance of different anaerobic digestion technologies for solid waste treatment, CSCE/EWRI of ASCE Environmental Engineering Conf., Niagara, 2002.

21. The 2018 Ageing Report: Economic and Budgetary Projections for the EU Member States, European Commission, (2016-2070), str. 306-308.

22. Kruta oporabljena goriva - Specifikacije i klase, HRN EN 15359:2012, HZN Glasilo 2/2012.

23. J. Muphy, R. Branu, P. Weiland, A. Wellinger, Biogas from Crop Digestion, IEA Bioenergy, Task 37 - Energy from Biogas, 2011.

24. J. Havukainen, V. Uusitalo, A. Niskanen, V. Kapustina, M. Horttanainen, Evaluation of methods for estimating energy performance of biogas production, Renew. Energy 66 (2014) 232-240, doi: https://doi.org/10.1016/j. renene.2013.12.011.
25. J. Fernandez-Rodriguez, M. Perez, L.I. Romero, Comparison of mesophilic and thermophilic dry anaerobic digestion of OFMW: Kinetic analysis, Chem. Eng. J. 232 (2013) 59-64, doi: https://doi.org/10.1016/j.cej.2013.07.066.

26. Izvješće o provedenom određivanju biorazgradivosti organske frakcije iz miješanog komunalnog otpada, Fakultet kemijskog inženjerstva i tehnologije Sveučilište u Zagrebu, 2020

27. R. Cossu, G. Fantinato, A. Sandon, Further steps in the standardization of $\mathrm{BOD}_{5} / \mathrm{COD}$ ratio as biological stability index for MSW, Waste Manage. 68 (2017) 16-23, doi: https://doi. org/10.1016/j.wasman.2017.06.035.

28. A. Jedrczak, M. Suchowska-Kisielewicz, A Comparison of Waste Stability Indices for Mechanical-Biological Waste Treatment and Composting Plants, International Journal of Environmental Research and Public Health 15 (2018) 2585, doi: https://doi.org/10.3390/ijerph15112585.

29. URL: https://novac.jutarnji.hr/novac/tvrtka-iz-slavonije-koristi-otpad-s-farmi-kako-bi-proizveli-struju-za-12-tisuca-kucanstava-10410094 (15. 2. 2021.), Jutarnji list, objavljeno: 24. lipnja 2020.

30. Energija u Hrvatskoj - Godišnji energetski pregled 2018., Ministarstvo zaštite okoliša i energetike, Zagreb, 2019

\section{SUMMARY}

\section{Projection of the Amount and Energy Potential of Mixed Municipal Waste in the Republic of Croatia

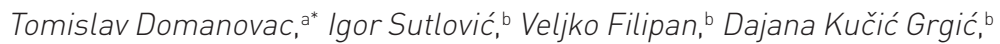 \\ Monika Šabić Runjavec, ${ }^{b}$ and Marija Vuković Domanovac ${ }^{b}$
}

In the Republic of Croatia, municipal waste management is prescribed by legal and other strategic and planning documents that set the goals of waste management, which include separate collection for material recovery, i.e., recycling. The remaining mixed municipal waste needs to be treated before final disposal. This treatment involves the implementation of mechanical-biological and energy recovery, most often the production of fuel from waste of standardised quality or direct production of electricity and heat from biogas produced at cogeneration plants within waste management centres.

In accordance with the stated objectives of waste management and their assumed fulfilment, a projection of waste quantities was made. According to the projection, out of the total generated annual amount of municipal waste in 2026 of about 1.54 million tons, about 753,000 tyear-1 need to be processed at waste management centres. Mechanical-biological treatment of waste, which for the purposes of this analysis includes mechanical treatment and refining of the fuel fraction and the combined biodegradable fraction of mixed municipal waste in anaerobic and aerobic conditions, it is possible to produce solid fuel from waste in the amount of about 298,000 tyear $^{-1}$ and about $41.7 \cdot 10^{6} \mathrm{Nm}^{3}$ of biogas. If the same biological treatment of waste is assumed for separately collected biowaste, then an additional annual production of about $26.2 \cdot 10^{6} \mathrm{Nm}^{3}$ of biogas can be expected.

The total energy potential by waste recovery is about $5.3 \mathrm{PJ}$, or about $3.71 \%$ from the sector of total general energy consumption for 2018.

\section{Keywords}

Municipal waste, waste quantities, waste composition, waste energy potential, biogas

\author{
IPZ UNIPROJEKT TERRA \\ Voćarska cesta 68, 10000 Zagreb \\ Republic of Croatia \\ b University of Zagreb, \\ Faculty of Chemical Engineering and Technology \\ Marulićev trg 19, 10000 Zagreb \\ Republic of Croatia
}

Original scientific paper

Received January 8, 2021 Accepted February 24, 2021 